\title{
ACCURATE APPROXIMATIONS FOR THE RIEMANN-STIELTJES INTEGRAL VIA THEORY OF INEQUALITIES
}

\author{
S. S. DRAGOMIR
}

Abstract. Accurate approximations for the Riemann-Stieltjes integral by the use of various recent inequalities for the generalised Čebyšev functional introduced in 1998 by Dragomir \& Fedotov are surveyed. Applications in deriving sharp inequalities of Grüss' type are also given.

Mathematics subject classification (2000): 26D15, 26D10, 41A55.

Keywords and phrases: Riemann-Stieltjes integral, $(l, L)$-Lipschitzian functions, Integral inequalities, Čebyšev, Grüss, Ostrowski and Lupaş type inequalities.

\section{REFERENCES}

[1] P. Cerone, W.-S. Cheung And S. S. Dragomir, On Ostrowski type inequalities for Stieltjes integrals with absolutely continuous integrands and integrators of bounded variation, Comput. Math. Appl. 54 (2007), no. 2, 183-191.

[2] P. Cerone AND S. S. DRAgomir, Approximation of the Stieltjes integral and application in numerical integration, Applications of Math., 51(1) (2006), 37-47.

[3] P. Cerone and S. S. Dragomir, New bounds for the Čebyšev functional, Appl. Math. Lett., 18 (2005), 603-611.

[4] P. CERone And S. S. DRAGOMiR, A refinement of the Grüss inequality and applications, Tamkang J. Math. 38(2007), No. 1, 37-49. Preprint RGMIA Res. Rep. Coll., 5(2) (2002), Art. 14.

[Online: http://rgmia.vu.edu.au/v8n2.html].

[5] P. Cerone And S. S. Dragomir, New upper and lower bounds for the Cebysev functional, J. Inequal. Pure and Appl. Math., 3(5) (2002), Article 77. [Online: http://jipam.vu.edu.au/ article.php?sid=229].

[6] P. Cerone And S. S. Dragomir, Bounding the Čebyšev functional for the Riemann-Stieltjes integral via a Beesack inequality and applications, Preprint RGMIA Res. Rep. Coll., 11(2008), to appear.

[7] P. L. CheByshev, Sur les expressions approximatives des intègrals dèfinis par les outres prises entre les même limites, Proc. Math. Soc. Charkov, 2 (1882), 93-98.

[8] X.-L. Cheng And J. Sun, Note on the perturbed trapezoid inequality, J. Inequal. Pure \& Appl. Math., 3(2) (2002), Art. 21 [Online: http://jipam.vu.edu.au/article.php?sid=181].

[9] W.-S. CheUng AND S. S. DRAGOMIR, Two Ostrowski type inequalities for the Stieltjes integral of monotonic functions, Bull. Austral. Math. Soc. 75 (2007), no. 2, 299-311.

[10] S. S. DRAGOMIR, Sharp bounds of Čebyšev functional for Stieltjes integrals and applications, Bull. Austral. Math. Soc., 67(2) (2003), 257-266.

[11] S. S. DRAGOMIR, New estimates of the Čebyšev functional for Stieltjes integrals and applications, J. Korean Math. Soc., 41(2) (2004), 249-264.

[12] S. S. Dragomir, A sharp bound of the Čebyšev functional for the Riemann-Stieltjes integral and applications, J. Inequalities \& Applications, Vol. 2008, [Online: http://www.hindawi.com/ GetArticle.aspx?doi=10.1155/2008/824610 ] .

[13] S. S. Dragomir, On the Ostrowski's inequality for Riemann-Stieltjes integral and applications, Korean J. Comput. Appl. Math. 7 (2000), no. 3, 611-627.

[14] S. S. DRAGOMIR, Some inequalities of midpoint and trapezoid type for the Riemann-Stieltjes integral, Nonlinear Anal. 47 (2001), no. 4, 2333-2340. 
[15] S. S. DRAGOMIR, Inequalities of Grüss type for the Stieltjes integral, Kragujevac J. Math., 26 (2004), 89-122.

[16] S. S. DRAgomir, A generalisation of Cerone's identity and applications, Tamsui Oxf. J. Math. Sci. 23 (2007), no. 1, 79-90. Preprint RGMIA Res. Rep. Coll. 8(2005), No. 2, Article 19.

[Online: http://www.staff .vu.edu.au/rgmia/v8n2.asp] .

[17] S. S. DRAGOMIR, Inequalities for Stieltjes integrals with convex integrators and applications, Appl. Math. Lett., 20 (2007), 123-130.

[18] S. S. DRAGOMIR, Accurate approximations of the Riemann-Stieltjes integral with $(l, L)$-Lipschitzian integrators, AIP Conf. Proc. 939, Numerical Anal. \& Appl. Math., Ed. T.H. Simos et al., pp. 686-690. Preprint RGMIA Res. Rep. Coll. 10(2007), No. 3, Article 5.

[Online: http://rgmia.vu.edu.au/v10n3.html] .

[19] S. S. DRAGOMIR, Approximating the Riemann-Stieltjes integral via a Cebysev type functional, Preprint RGMIA Res. Rep. Coll. 10(2007), Supplement, Article 18.

[Online: http://rgmia.vu.edu.au/v10(E).html].

[20] S. S. DRAGOMIR, Sharp Grüss-type inequalities for functions whose derivatives are of bounded variation, J. Inequal. Pure Appl. Math. 8 (2007), no. 4, Article 117, 13 pp. [Online: http://jipam.vu.edu.au/article.php?sid=908].

[21] S. S. DRAGOMIR AND I. Fedotov, An inequality of Grüss type for the Riemann-Stieltjes integral and applications for special means, Tamkang J. Math., 29(4) (1998), 287-292.

[22] S. S. DRAGOMIR AND I. Fedotov, A Grüss type inequality for mappings of bounded variation and applications to numerical analysis, Nonlinear Funct. Anal. Appl., 6(3) (2001), 425-433.

[23] G. GRÜSS, Über das Maximum das absoluten Betrages von $\frac{1}{b-a} \int_{a}^{b} f(x) g(x) d x-\frac{1}{(b-a)^{2}} \int_{a}^{b} f(x) d x$. $\int_{a}^{b} g(x) d x$, Math. Z., 39 (1934), 215-226.

[24] Z. LIU, Refinement of an inequality of Grüss type for Riemann-Stieltjes integral, Soochow J. Math., 30(4) (2004), 483-489.

[25] A. LuPAş, The best constant in an integral inequality, Mathematica (Cluj), 15 (38) (1973), No. 2, 219-222.

[26] A. M. Ostrowski, On an integral inequality, Aequationes Math., 4 (1970), 358-373. 